\title{
Mental Health Determinants in Turkey: Investigating an Extensive List of Variables
}

\author{
Abdullah Tirgil \\ Aysun Hizıroğlu Aygün
}

\begin{abstract}
This study examines the determinants of mental health in Turkey over a broad perspective including sociodemographic factors, health/lifestyle choices, home/neighborhood environment, social interactions, and workplace environment in Turkey. We implement a linear regression model to analyze the factors associated with mental well-being among adults. For this purpose, we utilize individual-level data obtained from the Turkey Health Surveys implemented by the Turkish Statistical Institute (TurkStat) between 2008-2012. Our results suggest men to report a higher mental health score than women despite controlling for a broad set of observable characteristics. Exposure to noise, violence, and crime at home or in the neighborhood are significantly related to lower mental health scores, especially for women. In contrast, employment is only associated with higher mental health scores for men. Importantly, household income does not appear to be as crucial as non-financial variables such as good health and having someone to trust in case of a severe problem. In addition, rude behavior and discrimination at workplace negatively affect mental well-being for both women and men. We suggest promoting non-financial variables such as trust in others, good health, and a peaceful environment at home, at work, and in the neighborhood in people's lives.
\end{abstract}

Keywords: Depression, mental well-being, lifestyle, social capital, financial factors, non-financial variables, Mental Health Inventory-5, Turkey, Turkey Health Survey.

Öz: Bu çalışma ruh sağlığı belirleyicilerini; sosyodemografik faktörleri, bireylerin sağlık ve yaşam tarzı seçimlerini, ev ve çevresel faktörleri, sosyal sermayeyi ve çalışma ortamını da işin içerisine katarak geniş bir perspektifle ele almaktadır. Bu çalışmada, lineer regresyon modelleri kullanılarak ruh sağlığıyla ilişkili faktörler yetişkin bireyler için incelenmektedir. Bunun için Türkiye İstatistik Kurumu tarafından yapılan, 2008-2012 yılları arasını kapsayan ve bütün Türkiye için temsil gücü bulunan Türkiye Sağlık Araştırması anketi verileri temel alınmıştır. Bulgularımıza göre, erkeklerin kadınlara kıyasla ruh sağlığı bakımından daha yüksek skora sahip oldukları ortaya çıkmaktadır. Çevredeki ses ve gürültü, ev veya çevredeki şiddet ve suçların özellikle kadınlarda düşük ruh sağlığı skoruyla ilişkili olduğu gözlemlenmiştir. Bunun yanında iş sahibi olmanın sadece erkeklerin ruh sağlığını olumlu etkilediği görülmüştür. Diğer önemli bir sonuç ise, hane halkı gelirinin, kişinin sağlığı ve çevresinde güvenebileceği insanların olması gibi parasal olmayan faktörlere nazaran ruh sağlı̆̆ını çok az ölçüde etkilediğinin gözlemlenmesidir. Ayrıca işyerinde maruz kalınan ayrımcılık ve kaba davranışların her iki cinsiyetin ruh sağlığını olumsuz yönde etkilediği gözlemlenmiştir. Araştırmamızdan çıkan sonuçlar başkalarına güven, sağlık, evde, iş yerinde ve çevrede huzurlu bir ortamın oluşturulması gibi maddi olmayan değerlerin kişilerin hayatında fark yaratacağı sonucuna işaret eder.

Anahtar Kelimeler: Depresyon, ruh sağlığı, yaşam tarzı, sosyal sermaye, parasal faktörler, parasal olmayan değişkenler, MHİ-5, Türkiye Sağlık Araştırması. 


\section{Introduction}

The World Health Organization (WHO) defines health most generally as "physical, mental, and social well-being." However, the indicators of social well-being element on this list were not deemed as important as the physical well-being indicators for a long time (WHO, 2005). In addition, mental health often goes unnoticed when discussing health problems in developing countries. Indeed, these countries need to address more vital issues such as infant mortality or shorter life expectancy. However, WHO emphasizes the importance of mental health as an essential component of health and the promotion of mental health to unquestionably improve people's well-being.

Turkey has experienced improvements in physical health outcomes for its population. A Health Transformation Program (HTP) has been implemented to improve efficiency and equality in the health care system (Akdag, 2011). As a result of significant reforms, Turkey has increased the people's access to health care services, especially those with lower income (Tirgil et al., 2018). Public coverage for core health services is provided to $99.2 \%$ of the population, a rather large figure when compared to other developing countries (Organisation for Economic Co-operation and Development [OECD], 2017). The infant mortality rate in Turkey decreased from 16.2 to 9.2 deaths in 1,000 live births within the last decade (OECD, 2019), and life expectancy at birth has reached 78.2 years (OECD, 2017). These improvements in health outcomes can be attributed to multiple factors such as higher incomes, educational attainment, and reforms in the health system. For instance, Turkey's GDP per capita increased from 10,640 to 14,870 (constant 2010 US\$) over the last decade (World Bank, 2020). The percentage of the population with at least a high school diploma for those 25 years of age or older has increased from $24.5 \%$ to $40 \%$ since 2008 (TurkStat, 2018).

Meanwhile, the prevalence of chronic depression among women in Turkey exceeded 14\% in 2014, with Turkey ranking third among European countries for this statistic after Portugal and Iceland (OECD, 2017). Even though men are less likely than women to report depression (less than $8 \%$ of men reported having chronic depression), $75 \%$ of the 3,161 suicides committed in 2018 were committed by men (Turkstat, 2019).

As part of the HTP, Turkey launched community-based mental health care services, first piloting them in Bolu Province in May 2008 to provide follow-up and therapeutic services for those diagnosed with severe mental health disorders. The centers have spread across the country over the years and offer assistance in many cities. The purpose of the mental health services offered in these centers is 
to prevent having to hospitalize mentally ill individuals and to integrate them into society as much as possible. In this way, the centers can reduce losses in the labor force and lead these individuals to get involved in and contribute to society (Ozden \& Coban, 2018).

In this paper, we examine the predictors of mental health in Turkey in relation to demographics, economics, and health/lifestyle. We also extend the existing literature by investigating the relationship the variables of home/neighborhood and workplace environments have with mental well-being in the context of Turkey as a developing country. Thus, this is the first study to the best of our knowledge to investigate the relationship workplace and home/neighborhood environments have with the mental health of people in Turkey in a broad perspective. All but one of the previous studies (i.e., Kose, 2020) had studied the determinants of mental health using a local perspective. Therefore, their findings cannot be generalized to Turkey's population. As such, our findings contribute to a better understanding of the link the observed variables have with mental health so that authorities can take the necessary policy actions to improve mental well-being. In comparison to the scant literature investigating mental health in Turkey, a wealth of literature is found here on life satisfaction and happiness. These articles have collected information using self-rated scales on life satisfaction and happiness. Examples of these surveys are the World Values Survey, Life in Transition Survey, and TurkStat's Life Satisfaction Survey (Selim, 2008; Dumludag, 2013; Eren \& Aş1c1 2017.) Our study relies on a health survey questionnaire, and our method of constructing the dependent variable differs from these studies.

Kose (2020) studied the relationship between gender and mental health in Turkey and found females to report having a lower mental health status compared to the males and women to be more likely to use mental health care services than men. Our study aims to extend their analysis by including additional factors that had been neglected in the previous literature such as health status, home/neighborhood environment, and relations in the workplace. These additional variables comprise the focus of our analysis, within which we also cover a longer time period to take into account the evolution of mental well-being through different predictors, this being another missing aspect in the current literature related to Turkey.

Scholars have previously analyzed certain combinations of these characteristics in the relationship to mental health for different countries. Studies show individual risk factors such as being female or of younger age, living alone, living in a large household, being unmarried, having low income or low educational attainment, 
being unemployed, and having bad health lead to poor mental health (Mundt et al., 2014; Lam \& Boey, 2005; Dalgard et al., 2006; Gruebner et al., 2012; Chou \& Cheung, 2013; Stankunas et al., 2006; Dong et al., 2014; Hamad et al., 2008; Henderson et al., 2005). Silva et al. (2016) provided a comprehensive review of these studies. The majority of studies implemented for identifying the social determinants of mental health were focused on developed countries such as Canada (Affleck et al., 2018; Caron et al., 2012), the United States (Kendler \& Gardner, 2014, Brisson et al., 2014; Gary et al., 2007; Ajrouch et al., 2010; Miranda et al., 2005), Australia (Jokela, 2014), Finland (Joutsenniemi et al., 2006), and Japan (Oshio et al., 2013).

Studies using developing countries' data have found mental well-being to be associated with food sufficiency and sanitation in Bangladesh, South Africa, and Israel (Gruebner et al., 2012; Sorsdahl et al., 2011; German et al., 2011); economic resources in Mexican low-income families (Gorn et al., 2005); and smaller household size, higher educational attainment, and income stability in South Africa (Hamad et al., 2008). One study investigated the relationship between individual-level characteristics and depression symptoms using the Patient Health Questionnaire (PHQ-9) among Chinese adults in the US (Dong et al., 2014). Their findings indicated low income, younger age, being unmarried, and being female to statistically significantly increase the presence of depression symptoms. Another study on South-African adults showed lower-income stability, larger household size, and lower subjective social status to all be associated with the presence of depression symptoms (Hamad et al., 2008).

While individual-level factors have great importance in assessing one's mental well-being, research has also suggested neighborhood characteristics including neighborhood socioeconomic status and social disorder to also affect mental health (Kim, 2008; Mundt et al., 2014; Fone et al., 2007; Fone et al., 2013; Gale et al., 2011; Stockdale et al., 2007). For example, Mundt et al. (2014) reported living in a socially disadvantaged urban area to be more likely to result in worse mental health outcomes among Berlin residents. Gale et al. (2011) investigated the importance of neighborhood factors on older people's mental health and found those who had reported fewer neighborhood problems to have higher levels of mental well-being. Another critical study showed exposure to violence in the neighborhood to be associated with lower levels of mental well-being among adults in the United States (Stockdale et al., 2007). Moreover, one study found neighborhood noise to be associated with poor mental health outcomes across Europe (Shiue, 2015).

A strand of literature has focused on the relationship between social capital and mental health. Social capital can be divided into two parts (i.e., structural and 
cognitive dimensions) that impact individual mental well-being. Structural social capital includes information on organizational membership and connectedness. Meanwhile, cognitive social capital entails a sense of belonging, trust, and shared values (Silva et al., 2016). For example, Fujiwara and Kawachi (2008) investigated the link cognitive and structural social capital have with depression in the United States. They measured cognitive social capital using three dimensions (i.e., social trust, sense of belonging, and mutual aid) and found individuals who trust their neighbors to have lower risks of developing a mental health disorder. Another study by Fujiwara and Kawachi (2008) focused on the impact cognitive social capital (i.e., social trust and sense of belonging) have on the mental and physical health of adult twins in the USA. While a significant relationship was shown between mental health and social belonging for dizygotic twins, the findings revealed no significant relationship between mental health and cognitive social capital for monozygotic twins. Another critical study investigated the relationship between workplace social capital and mental well-being for Chinese employees (Gao et al., 2014). They found higher workplace social capital to lead to employees facing fewer mental health problems. In this study, we focus among other things on the link trust in others, a cognitive component of social capital, has with mental health.

In our analyses, we incorporate variables related to a broad set of predictors in order to understand mental health determinants comprehensively. These variables include economic and demographic characteristics as well as the measures of lifestyle and home/neighborhood environment reported by the interviewees. We also check for social capital, which we measure using the availability of having someone to trust in the case of a severe problem. Furthermore, we also extend our analysis by including workplace environment variables to see whether exposure to rude behavior or feeling discriminated in the workplace has any connection with mental well-being. In this manner, our study is thefirst to analyze the mental health risk factors of workplace and home/neighborhood environments in Turkey.

Our study is based on psychosocial theory (Billings \& Moos, 1982) which builds an integrative framework in explaining the occurrence of depression. According to this theory, people face stressors (i.e., stressful events such as divorce or job loss, life strains such as social roles as parents or spouses, and micro stressors such as noise, rush hour traffic, or concerns about money). Environmental resources (i.e., the emotional support from family, social networks, or work), personal resources (i.e., sense of environmental mastery such as internal versus external locus of control, attributional styles such as perceived controllability vs. uncontrollability 
of the environment, and interpersonal skills and orientation) together determine the effect stressors have on people's mental well-being. These factors can affect depression and personal functioning directly or indirectly through appraisal and coping mechanisms. According to Billings and Moos, environmental and personal resources and stressors in short together determine the presence of depression. In this study, we aim to test which of the observable characteristics among these factors are significant determinants of mental well-being by incorporating a broad list of covariates into our analysis.

\section{Data and Methodology}

We utilize Turkey's Health Survey (THS) conducted biennially by TurkStat, allowing us to observe self-reported feelings for generating an index for the mental health score. THS is representative of Turkey's population. Interviewed households have been selected from a sample based on the Address-Based Population Registration System. Household members above the age of 15 have been interviewed about their health status, health care use, and health care needs. All the information THS has collected is self-reported. Data were collected using face-to-face interviews. We use repeated cross-sections of the 2008, 2010 and 2012 surveys in our analysis. We also use data from earlier years and have left out the more recent 2014 and 2016 surveys because the more recent data does not include information regarding individuals' workplace and home/neighborhood environments, which is the main focus of our analysis.

More than 14,000 observations occurred in the 2008 and 2010 surveys each, and more than 28,000 in the 2012 survey. We did not need to obtain ethical approval for the study as we are using data collected by TurkStat. Although the micro data from the THS is not publicly available, we were granted access to the anonymized version of the datasets after completing the application process for researchers who want to use TurkStat's micro-level data.

Our main goal is to assess the factors impacting individuals' self-reported mental health. For this purpose, we construct a five-variable mental health index (MHI-5) in accordance with the Short Form Health Survey (SF-36) guidelines (Ware et al., 1993). SF-36 is a 36-item form for collecting information on patient health as reported by the patients. Its mental health component consists of five questions and is used as a screening questionnaire for detecting depression symptoms. Although it is a very short questionnaire, it has been shown to produce 
results that highly correlate with what alternative questionnaires conclude about respondents' mental health (Berwick et al. 1991; Rumpf et al. 2001; Yamazaki et al. 2005). MHI-5 combines information based on the answers to the following questions in THS: "In the last four weeks how often have you felt (i) very nervous, (ii) brokenhearted and depressed, (iii) calm and quiet, (iv) thought nothing could cheer you up and felt melancholic, and (v) happy?" The answers are a five-point Likert-type ranging from 1 = Always to 5 = Never. The original MHI- 5 is a six-point Likert-type questionnaire. THS offers one less answer option than the original, leaving out the option "a good bit of the time." We believe this will not affect the international comparability of our analysis because we have rescaled the scores to fit the 0-100 range as suggested by the guideline. Answers to (iii) calm and quiet and (v) happy are reverse scored as these are positive feelings. We handle missing values as Ware et al (1993) suggested: If a respondent has filled in values for at least half of the five feeling questions, we compute any incomplete values by taking the average score of the filled frequencies. We treat responses such as "I do not know" and "I do not want to answer" as incomplete.

Our score for the mental health variables generated in this manner is not a perfect measure of mental health as the questionnaire was not implemented by a health worker in a clinical setting. Therefore, our analysis aims to find the factors that are associated with a higher (or lower) mental well-being score as reported by the individuals, and we have interpreted our results accordingly.

Table 1 provides summary statistics of the control variables used in our analysis of the 2008-2012 period. We have documented the results in Tables 1-5 in three groups: (a) all, (b) women, and (c) men. Our aim is to capture the heterogenous relation the demographic and socio-economic factors have with mental well-being as these may diverge for men and women. As mentioned above, a considerable amount of studies has concluded women to be more likely to report feelings of depression than men; therefore, we have separately analyzed the factors associated with mental well-being by gender.

As seen in Table 1, the mean age in the adult sample of THS' 2008, 2010, and 2012 surveys combined is 41.63 years, and $55 \%$ of the respondents are women. On average, a household has 3.71 total members and 0.91 kids, indicating the presence of other family members in the household; $72 \%$ of the respondents live in urban areas (urban is defined as having a population greater than 20,000), and $69 \%$ are married. The mean education level is 7.18 years overall ( 8.16 years for men 
insan \& toplum

and 6.37 years for women). On average, $37 \%$ of the respondents are employed, with men being more likely to be employed (59\%) compared to women (19\%). Even though making distinctions in terms of unemployment/inactive would have been interesting, THS data does not allow for generating a conventional category for this.

Table 1

Descriptive Statistics for All Variables

\begin{tabular}{|c|c|c|c|}
\hline & All & Women & Men \\
\hline \multicolumn{4}{|l|}{ Dependent variable } \\
\hline \multirow{2}{*}{ MHI-5 } & 62.29 & 61.10 & 63.73 \\
\hline & [14.00] & [14.15] & [13.68] \\
\hline \multicolumn{4}{|l|}{ Demographic and economic variables } \\
\hline \multirow{2}{*}{ Age } & 41.63 & 41.52 & 41.76 \\
\hline & [17.34] & [17.41] & [17.25] \\
\hline \multirow{2}{*}{ Female } & 0.55 & (1) & 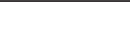 \\
\hline & {$[0.50]$} & - & - \\
\hline \multirow{2}{*}{ Household size } & 3.71 & 3.68 & 3.75 \\
\hline & {$[1.80]$} & {$[1.83]$} & {$[1.75]$} \\
\hline \multirow{2}{*}{ Number of kids } & 0.91 & 0.94 & 0.86 \\
\hline & {$[1.20]$} & {$[1.23]$} & {$[1.16]$} \\
\hline \multirow{2}{*}{ Urban } & 0.72 & 0.71 & 0.72 \\
\hline & {$[0.45]$} & {$[0.45]$} & {$[0.45]$} \\
\hline \multirow{2}{*}{ Married } & 0.69 & 0.67 & 0.71 \\
\hline & {$[0.46]$} & {$[0.47]$} & {$[0.45]$} \\
\hline \multirow{2}{*}{ Education } & 7.18 & 6.37 & 8.16 \\
\hline & {$[4.58]$} & {$[4.56]$} & {$[4.42]$} \\
\hline \multirow{2}{*}{ Employed } & 0.37 & 0.19 & 0.59 \\
\hline & {$[0.48]$} & {$[0.39]$} & {$[0.49]$} \\
\hline \multirow{2}{*}{ Per capita income } & 219.65 & 217.38 & 222.41 \\
\hline & [189.35] & [187.03] & [192.09] \\
\hline \multicolumn{4}{|l|}{ Home/neighborhood environment } \\
\hline \multirow{2}{*}{ Home noise } & 0.40 & 0.41 & 0.40 \\
\hline & {$[0.49]$} & {$[0.49]$} & {$[0.49]$} \\
\hline \multirow{2}{*}{ Home or neighborhood crime/violence } & 0.27 & 0.28 & 0.26 \\
\hline & {$[0.44]$} & {$[0.45]$} & {$[0.44]$} \\
\hline
\end{tabular}




\begin{tabular}{lccc}
\hline Health/lifestyle & & & \\
\hline \multirow{2}{*}{ Alcohol } & 0.22 & 0.09 & 0.37 \\
& {$[0.41]$} & {$[0.28]$} & {$[0.48]$} \\
\multirow{2}{*}{ BMI } & 25.81 & 25.91 & 25.71 \\
& {$[4.90]$} & {$[5.48]$} & {$[4.17]$} \\
Good health & 0.65 & 0.58 & 0.73 \\
& {$[0.48]$} & {$[0.49]$} & {$[0.45]$} \\
\hline Social capital & & & \\
Trust in others & 0.95 & 0.95 & 0.95 \\
\hline Work environment & {$[0.21]$} & {$[0.21]$} & {$[0.22]$} \\
\hline \multirow{2}{*}{ Rude behavior } & & & \\
\hline \multirow{2}{*}{ Discrimination } & 0.08 & 0.07 & 0.08 \\
\hline$n$ & {$[0.26]$} & {$[0.26]$} & {$[0.27]$} \\
\hline
\end{tabular}

Notes: Means are reported. Standard deviations in brackets.

Source: Turkey's Health Surveys (2008, 2010, 2012), author's analysis

The data contain information on the ranges of monthly total household income. Households' income brackets are composed of 10 distinct categories: Less than 350 Turkish Lira (TL), 351-500 TL, 501-620 TL, 621-750 TL, 751-900 TL, 9011,100 TL, 1,101-1,300 TL, 1,301-1,700 TL, 1,701-2,300 TL, and more than 2,300 TL. We obtained the mid-point of each bracket and assigned a numeric variable to households based on their categories. Accordingly, we derived per capita income for each individual in a household by dividing the mid-point income value by the number of people in the household. We have also adjusted the income variable for deflation based on 2003 values. The average household per capita income calculated in this way is $219.65 \mathrm{TL}$.

The variables for home/neighborhood environment that we have included in our analyses involve exposure to noise and crime; $40 \%$ of respondents reported being exposed to noise (traffic, railway traffic, air traffic, factories, neighbors, restaurants, pubs, night clubs) in the past 12 months, and $27 \%$ reported the presence of crime or violence at home or in the neighborhood in the last 12 months.

Among the health/lifestyle characteristics that we have used in our analyses, alcohol use varies greatly between men and women; $37 \%$ of men reported drinking alcohol, whereas only $9 \%$ of women drink alcohol. The mean body mass index (BMI) in our sample, measured as weight $(\mathrm{kg}) /$ height (meters) squared, is very similar for 
men and women with an average value of 25.81. THS also asked the respondents to rate their overall health status with the following question: "How is your overall health status?" The possible answers to this question are: Very good, good, fair, bad, and very bad; we have grouped the responses of very good and good as good health and the remaining responses as bad health to facilitate interpreting the variable of health status. Of the survey respondents, $65 \%$ stated having good or very good overall health, with men also being more likely to report their overall health as good/ excellent (73\%) compared to women (58\%). Additionally, 95\% of both men and women reported having at least one person to trust when facing a serious personal problem.

Lastly, $8 \%$ of the respondents confirmed having been exposed to rude behavior, with $7 \%$ of respondents reporting to have experienced discrimination at the workplace. These work environment variables naturally are only available for respondents who are employed.

We have implemented multivariate regression analyses to investigate the predictors of mental health using the following regression equation:

$$
\begin{aligned}
& y_{i t}=\alpha_{0}+\alpha_{1} \text { Age }_{i t}+\alpha_{2} \text { Age }_{i t}{ }^{2}+\alpha_{3} \text { Female }_{i t}+\alpha_{4} \text { Married }_{i t}+\alpha_{5} \text { Education }_{i t}+\alpha_{6} \text { Urban }_{i t}+ \\
& \alpha_{7} \text { NbrKids }_{i t}+\alpha_{8} \text { HH }_{\text {size }}+\alpha_{9} \text { HHincome }_{i t}+\alpha_{10} \text { Homenois }_{i t}+\alpha_{11} \text { Homecrime }_{i t}+ \\
& \alpha_{12} \text { Alcohol }_{i t}+\alpha_{13} \text { BMI }_{i t}+\alpha_{14} \text { Health }_{i t}+\alpha_{15} \text { Trust }_{i t}+\alpha_{16} \text { Rudebehavior }_{i t}+ \\
& \alpha_{17} \text { Discrimination }_{i t}+\varepsilon_{i t}
\end{aligned}
$$

where:

- $y_{i t}=$ the mental health score (MHI-5) of an individual $i$ at time $t$,

- $A g e_{i t}=$ Age of individual $i$ at time $t$,

- $A g e_{i t}{ }^{2}=$ Square of the age of individual $i$ at time $t$,

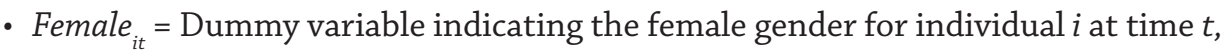

- Married $_{i t}=$ Marital status of individual $i$ at time $t$; its value is 1 if married, otherwise it equals 0 ,

- Education $_{i t}=$ Education in years of the individual $i$ at time $t$,

- $U_{r b a n}=$ Dummy variable indicating urban residence for individual $i$ at time $t$,

- $N b r K i d s_{i t}=$ The number of children living in the household of individual $i$ at time $t$,

- $H H$ size $_{i t}=$ Total number of people living in the household of individual $i$ at time $t$,

- HHincome ${ }_{i t}=$ Per person household income in TL (adjusted for 2003) in home of individual $i$ at time $t$, 
- Homenoise ${ }_{i t}=$ Dummy variable with a value of 1 if individual $i$ at time $t$ reported exposure to noise at home in the last 12 months,

- Homecrime $_{i t}=$ Dummy variable with a value of 1 if individual $i$ at time $t$ reports exposure to crime and violence at home in the last 12 months,

- Alcohol $_{i t}=$ Dummy variable with a value of 1 if individual $i$ at time $t$, ever used alcohol,

- $B M I_{i t}=$ Body mass index of individual $i$ at time $t$, calculated by self-reported height (m) and weight (kg),

- Health ${ }_{i t}$ Dummy variable with value of 1 if individual $i$ at time $t$ reports good/ very good overall health,

- Trust $_{i t}=$ Dummy variable with a value of 1 if individual $i$ at time $t$ reports having at least one person to trust in case of a serious personal problem,

- Rudebehavior $_{i t}=$ Dummy variable with a value of 1 if individual $i$ at time $t$ reports exposure to rude behavior at the workplace,

- Discrimination $_{i t}=$ Dummy variable with a value of 1 if individual $i$ at time $t$ reports feeling discriminated at the workplace.

We also checked for year and region fixed effects in all our regressions. The error terms are clustered at the household level.

Utilizing a higher number of control variables has been required to determine the associated risk factors of mental health. Therefore, we report the correlation matrices and the variances for inflation factors to verify that multicollinearity is not a problem in our pooled multivariate analyses. The Appendix presents the results where we see multicollinearity is not an issue among our independent variables.

\section{Results}

We begin by reporting the results using the basic set of control variables (i.e., age and gender) as these are very often cited as the exogenous factors affecting mental well-being. We then add the demographic and economic variables (i.e., marital status, household size, number of children, urban/non-urban residency, education, employment status, and per capita income). Finally, we add home/neighborhood environment, health/lifestyle, and social capital characteristics. By doing so, we aim to observe whether extending the set of control variables improves the explanatory power of the regression analysis. Our regression analysis provides information about the characteristics that are positively or negatively related to mental health. The magnitude of the coefficients can be interpreted within the 0-100 scale. 
Table 2 provides coefficient estimates of the regression equations for distinct subsamples where the dependent variable is the MHI-5 score. Here, we run multivariate regression models for our outcome variable, and in these regressions, we check only for the exogenous demographic characteristics (i.e., age, age squared, and a gender variable for female gender in Column 1 ). We include age squared in the regression analysis in order to test the linearity of mental health's relation with age. Because our data was collected over different years, we also add a year dummy covariate in order to control for how mental health scores change over time. The idea of adding a year dummy variable in the regression analysis is to avoid spurious regression outcomes as other unobserved changes may exist in different years. Hence, not including $f$ ixed annual effects in the regression may result in an incorrect interpretation of the correlation between the dependent and independent variables.

As seen in Table 2, mental health had improved for 2012 compared to the base year of 2008 (a higher MHI-5 score means better mental health). With respect to the results in Table 2, women's mean MHI- 5 score is 2.6 points less than men's when adjusted for age, age squared, and the year dummy. MHI- 5 score decreases with age for both men and women. For women, mental well-being declines with age in a decreasing pattern as suggested by the significantly negative coefficient of age squared; this implies that women's mental well-being first deteriorates then improves as they age.

\section{Table 2}

Regression Results for MHI-5 Score's Relationship with the Exogenous Demographic Variables

\begin{tabular}{lccc}
\hline & All & Women & Men \\
\hline \multirow{2}{*}{2010} & $0.378^{*}$ & 0.056 & $0.804^{* * *}$ \\
& $(0.208)$ & $(0.246)$ & $(0.264)$ \\
\hline \multirow{2}{*}{2012} & $3.237^{* * *}$ & $3.580^{* * *}$ & $2.846^{* * *}$ \\
& $(0.183)$ & $(0.217)$ & $(0.226)$ \\
\hline \multirow{2}{*}{ Age } & $-0.175^{* * *}$ & $-0.259^{* * *}$ & $-0.076^{* * *}$ \\
& $(0.016)$ & $(0.021)$ & $(0.023)$ \\
\multirow{2}{*}{ Age ${ }^{2}$} & $0.001^{* * *}$ & $0.002^{* * *}$ & 0.000 \\
\hline \multirow{2}{*}{ Female } & $(0.000)$ & $(0.000)$ & $(0.000)$ \\
\hline$r^{2}$ & $-2.613^{* * *}$ & - & - \\
\hline$n$ & $(0.102)$ & 0.024 & 0.011 \\
\hline
\end{tabular}

Notes: Robust standard errors are in parentheses. ${ }^{*} p<.1,{ }^{* *} p<.05,{ }^{* * *} p<.01$.

We cluster standard errors at household level. The analysis covers the period 2008-2012. 
Table 3 further extends the analysis by including the demographic and economic determinants as seen in Equation 1. The relationship between age and MHI-5 score is observed to be similar for men and women, indicating a U-shaped pattern. When the other control variables are held constant, women report 1.4-point lower MHI-5 score compared to men. In addition, both men and women show higher MHI- 5 scores with increased household size, the magnitude being larger for women. Interestingly, the number of kids is related to a lower MHI- 5 score, for which the magnitude is higher for women.

Furthermore, married individuals report greater mental well-being. Higher education levels are positively associated with higher MHI-5 scores. Each additional year of schooling is associated with a 0.309 point increase in MHI- 5 score. The marginal effect of years of education being smaller for women (0.299) than men (0.325) is impressive because men in our dataset on average have longer years of schooling than women, which may be interpreted as education having an increasing marginal return on mental health.

Moreover, employed men report higher MHI-5 scores than unemployed men. These results are consistent with the bread-winner role men have in Turkey, indicating that men feel better when they fulfill this role. On the other hand, employment is neither positively nor negatively related to MHI- 5 score for women. Finally, per capita income is positively related to higher mental health scores for both men and women.

\section{Table 3}

Regression Results for MHI-5 Score's Relationship with Demographic and Economic Variables

\begin{tabular}{llll}
\hline & All & Women & Men \\
\hline \multirow{2}{*}{ Age } & $-0.423^{* * *}$ & $-0.455^{* * *}$ & $-0.402^{* * *}$ \\
& $(0.024)$ & $(0.030)$ & $(0.039)$ \\
\hline \multirow{2}{*}{ Age $^{2}$} & $0.004^{* * *}$ & $0.004^{* * *}$ & $0.004^{* * *}$ \\
& $(0.000)$ & $(0.000)$ & $(0.000)$ \\
\hline \multirow{2}{*}{ Female } & $-1.419^{* * *}$ & & - \\
\hline \multirow{2}{*}{ Household size } & $(0.142)$ & - & $0.416^{* * *}$ \\
& $0.528^{* * *}$ & $0.649^{* * *}$ & $(0.103)$ \\
\hline \multirow{2}{*}{ Number of kids } & $(0.082)$ & $(0.094)$ & $-0.464^{* * *}$ \\
\hline \multirow{2}{*}{ Urban } & $-0.669^{* * *}$ & $-0.905^{* * *}$ & $(0.152)$ \\
\hline
\end{tabular}




\begin{tabular}{llll}
\hline Married & $\begin{array}{l}2.412^{* * *} \\
(0.200)\end{array}$ & $\begin{array}{l}2.291^{* * *} \\
(0.236)\end{array}$ & $\begin{array}{l}2.498^{* * *} \\
(0.350)\end{array}$ \\
\hline \multirow{2}{*}{ Education } & $0.309^{* * *}$ & $0.299^{* * *}$ & $0.325^{* * *}$ \\
& $(0.020)$ & $(0.026)$ & $(0.027)$ \\
\hline \multirow{2}{*}{ Employed } & $0.541^{* * *}$ & -0.364 & $0.978^{* * *}$ \\
\hline \multirow{2}{*}{ Per capita income } & $(0.171)$ & $(0.258)$ & $(0.241)$ \\
\hline $\mathrm{r}^{2}$ & $0.007^{* * *}$ & $0.008^{* * *}$ & $0.006^{* * *}$ \\
\hline$n$ & $(0.000)$ & $(0.001)$ & $(0.001)$ \\
\hline
\end{tabular}

Notes: Robust standard errors are in parentheses. ${ }^{*} p<.1,{ }^{* *} p<.05,{ }^{* * *} p<.01$. We cluster standard errors at household level. We adjust for demographic and economic variables in all models. The datasets cover the years 2008, 2010, and 2012. The F-test indicates that we can reject the null hypothesis that states all coefficients = 0 . Demographic and economic variables: age, age ${ }^{2}$, gender, household size, number of kids, urban, marital status, education in years, employment status, adjusted total household per capita income, 26 regions of Turkey, and year fixed effects.

Table 4 includes additional control variables for the home/neighborhood environment and health/lifestyle alongside the demographic and economic variables reported in Table 3. When we adjust for these additional variables in Table 4, urban residency is no longer associated with mental health score for either women or men. Being exposed to noise at home is related to a slightly lower mental health score for both genders. While exposure to crime or violence at home or in the neighborhood reduces women's MHI-5 score, the relationship is negative for men; however the coefficient is not precisely estimated.

\section{Table 4}

Regression Results for MHI-5 Score's Relationship with the Variables of Home/Neighborhood Environment, Health/Lifestyle, and Social Capital

\begin{tabular}{lccc}
\hline Demographic and economic variables & All & Women & Men \\
\hline Age & $-0.363^{* * *}$ & $-0.343^{* * *}$ & $-0.393^{* * *}$ \\
& $(0.028)$ & $(0.035)$ & $(0.042)$ \\
\hline Age $^{2}$ & $0.004^{* * *}$ & $0.004^{* * *}$ & $0.004^{* * *}$ \\
& $(0.000)$ & $(0.000)$ & $(0.000)$ \\
\hline Female & $-0.892^{* * *}$ & - & - \\
& $(0.158)$ & & \\
\hline Household size & $0.398^{* * *}$ & $0.482^{* * *}$ & $0.320^{* * *}$ \\
& $(0.088)$ & $(0.107)$ & $(0.106)$ \\
\hline Number of kids & $-0.520^{* * *}$ & $-0.725^{* * *}$ & $-0.355^{* *}$ \\
& $(0.125)$ & $(0.143)$ & $(0.157)$ \\
\hline
\end{tabular}




\begin{tabular}{|c|c|c|c|}
\hline Urban & $\begin{array}{l}-0.457^{* *} \\
(0.227)\end{array}$ & $\begin{array}{c}-0.536^{*} \\
(0.279) \\
\end{array}$ & $\begin{array}{c}-0.399 \\
(0.283) \\
\end{array}$ \\
\hline Married & $\begin{array}{l}2.217^{* * *} \\
(0.219)\end{array}$ & $\begin{array}{l}2.251^{1 * *} \\
(0.264)\end{array}$ & $\begin{array}{l}2.344^{n+} \\
(0.366)\end{array}$ \\
\hline Education & $\begin{array}{l}0.227^{* * *} \\
(0.021)\end{array}$ & $\begin{array}{l}0.193^{* * *} \\
(0.029)\end{array}$ & $\begin{array}{l}0.269^{n+1} \\
(0.029)\end{array}$ \\
\hline Employed & $\begin{array}{l}0.538^{\text {tw* }} \\
(0.179)\end{array}$ & $\begin{array}{c}-0.015 \\
(0.275) \\
\end{array}$ & $\begin{array}{l}0.749^{n+*} \\
(0.250)\end{array}$ \\
\hline Per capita income & $\begin{array}{l}0.005^{\text {t** }} \\
(0.001)\end{array}$ & $\begin{array}{l}0.006^{* * *} \\
(0.001)\end{array}$ & $\begin{array}{l}0.005^{2 *} \\
(0.001)\end{array}$ \\
\hline \multicolumn{4}{|l|}{ Home/neighborhood environment } \\
\hline Home noise & $\begin{array}{l}-1.846^{* *+} \\
(0.219)\end{array}$ & $\begin{array}{c}-1.789^{\prime \prime *} \\
(0.277) \\
\end{array}$ & $\begin{array}{l}-1.860 \\
(0.280) \\
\end{array}$ \\
\hline Home/neighborhood crime or violence & $\begin{array}{l}-1.995^{* * *} \\
(0.501)\end{array}$ & $\begin{array}{c}-3.472^{\prime * *} \\
(0.627)\end{array}$ & $\begin{array}{c}-0.694 \\
(0.699)\end{array}$ \\
\hline \multicolumn{4}{|l|}{ Health/lifestyle } \\
\hline Alcohol & $\begin{array}{l}-0.386^{*} \\
(0.210)\end{array}$ & $\begin{array}{c}-1.210^{* * * *} \\
(0.385)\end{array}$ & $\begin{array}{l}-0.322 \\
(0.246)\end{array}$ \\
\hline BMI & $\begin{array}{l}0.035^{* *} \\
(0.017)\end{array}$ & $\begin{array}{l}-0.014 \\
(0.021)\end{array}$ & $\begin{array}{l}0.083^{* *} \\
(0.027)\end{array}$ \\
\hline Good health & $\begin{array}{l}5.402^{* * *} \\
(0.186)\end{array}$ & $\begin{array}{l}5.800^{* * *} \\
(0.242)\end{array}$ & $\begin{array}{l}4.873^{* * *} \\
(0.269)\end{array}$ \\
\hline \multicolumn{4}{|l|}{ Social capital } \\
\hline Trust in others & $\begin{array}{l}4.906^{* * *} \\
(0.458)\end{array}$ & $\begin{array}{l}5.396^{* * *} \\
(0.574)\end{array}$ & $\begin{array}{l}4.441^{n *} \\
(0.635)\end{array}$ \\
\hline$r^{2}$ & 0.096 & 0.104 & 0.087 \\
\hline$n$ & 47,221 & 24,588 & 22,633 \\
\hline
\end{tabular}

Notes: Robust standard errors are in parentheses. ${ }^{*} p<.1,{ }^{* *} p<.05,{ }^{* * *} p<.01$. We cluster standard errors at the household level. We adjust for demographic and economic variables, home/neighborhood environment, health/lifestyle variables, and social capital variable in all models. The datasets cover the years 2008, 2010, and 2012. The F-test indicates that we can reject the null hypothesis that states all coefficients $=0$. Demographic and economic variables: age, age ${ }^{2}$, gender, household size, number of children, urban, marital status, education in years, employment status, adjusted total household per capita income, 26 regions of Turkey, and year fixed effects. Home/neighborhood environment variables: home noise and home/neighborhood crime or violence. Health/lifestyle variables: alcohol consumption, BMI, and health status. Social capital variable: whether you have someone to trust in case of a serious problem.

In terms of lifestyle variables, alcohol consumption is related to a lower mental health scores for women. For men, although the sign of the coefficient is negative, alcohol consumption does not have a statistically significant relationship with 
MHI-5. Interestingly, higher BMI values are related to higher MHI-5 scores for men. Furthermore, both good health and the social capital variable of trust in others are very significantly associated with higher mental well-being score when compared to the other control variables.

\section{Table 5}

Regression Results for MHI-5 Score's Relationship with Workplace Environment Variables for the Employed

\begin{tabular}{|c|c|c|c|}
\hline Demographic and economic variables & All & Women & Men \\
\hline Age & $\begin{array}{c}-0.156^{* * *} \\
(0.058)\end{array}$ & $\begin{array}{l}-0.265^{* *} \\
(0.104)\end{array}$ & $\begin{array}{l}-0.129^{*} \\
(0.068) \\
\end{array}$ \\
\hline $\mathrm{Age}^{2}$ & $\begin{array}{l}0.002^{* * *} \\
(0.001)\end{array}$ & $\begin{array}{l}0.003^{* * *} \\
(0.001)\end{array}$ & $\begin{array}{l}0.002^{* *} \\
(0.001)\end{array}$ \\
\hline Female & $\begin{array}{c}-1.459^{* * *} \\
(0.265) \\
\end{array}$ & - & - \\
\hline Household size & $\begin{array}{c}0.122 \\
(0.122) \\
\end{array}$ & $\begin{array}{c}0.316 \\
(0.219) \\
\end{array}$ & $\begin{array}{c}0.070 \\
(0.136)\end{array}$ \\
\hline Number of kids & $\begin{array}{l}-0.205 \\
(0.176) \\
\end{array}$ & $\begin{array}{l}-0.874^{* * *} \\
(0.321)\end{array}$ & $\begin{array}{l}-0.057 \\
(0.194) \\
\end{array}$ \\
\hline Urban & $\begin{array}{l}-0.741^{* *} \\
(0.325)\end{array}$ & $\begin{array}{l}-1.409^{* *} \\
(0.646)\end{array}$ & $\begin{array}{l}-0.586^{*} \\
(0.355) \\
\end{array}$ \\
\hline Married & $\begin{array}{l}1.920^{* * *} \\
(0.364)\end{array}$ & $\begin{array}{l}2.589^{* * *} \\
(0.582)\end{array}$ & $\begin{array}{l}1.596^{* * *} \\
(0.452)\end{array}$ \\
\hline Education & $\begin{array}{l}0.315^{* * *} \\
(0.031)\end{array}$ & $\begin{array}{l}0.247^{* * *} \\
(0.059)\end{array}$ & $\begin{array}{l}0.326^{* * *} \\
(0.035)\end{array}$ \\
\hline Per capita income & $\begin{array}{l}0.004^{* * *} \\
(0.001)\end{array}$ & $\begin{array}{l}0.006^{* * *} \\
(0.001)\end{array}$ & $\begin{array}{l}0.003^{* * *} \\
(0.001)\end{array}$ \\
\hline \multicolumn{4}{|l|}{ Home/neighborhood environment } \\
\hline Home noise & $\begin{array}{c}-1.780^{* * *} \\
(0.304) \\
\end{array}$ & $\begin{array}{l}-2.075^{* * *} \\
(0.610) \\
\end{array}$ & $\begin{array}{c}-1.699^{* * *} \\
(0.338)\end{array}$ \\
\hline Home or neighborhood crime/violence & $\begin{array}{l}-0.703 \\
(0.777) \\
\end{array}$ & $\begin{array}{l}-2.608^{*} \\
(1.334) \\
\end{array}$ & $\begin{array}{l}-0.196 \\
(0.881) \\
\end{array}$ \\
\hline \multicolumn{4}{|l|}{ Health/lifestyle } \\
\hline Alcohol & $\begin{array}{c}0.040 \\
(0.265) \\
\end{array}$ & $\begin{array}{c}0.010 \\
(0.615) \\
\end{array}$ & $\begin{array}{l}-0.048 \\
(0.291) \\
\end{array}$ \\
\hline BMI & $\begin{array}{c}0.022 \\
(0.029) \\
\end{array}$ & $\begin{array}{l}-0.008 \\
(0.052) \\
\end{array}$ & $\begin{array}{c}0.041 \\
(0.035) \\
\end{array}$ \\
\hline Good health & $\begin{array}{l}4.409^{* * *} \\
(0.305)\end{array}$ & $\begin{array}{l}5.218^{* * *} \\
(0.580)\end{array}$ & $\begin{array}{l}4.129^{* * *} \\
(0.354)\end{array}$ \\
\hline
\end{tabular}




\begin{tabular}{lccc}
\hline Social capital & & & \\
\hline Trust in others & $4.530^{* * *}$ & $5.660^{* * *}$ & $4.155^{* * *}$ \\
& $(0.759)$ & $(1.289)$ & $(0.868)$ \\
\hline Work environment & & & \\
\hline Rude behavior & $-2.776^{* * *}$ & $-2.279^{* *}$ & $-2.926^{* * *}$ \\
& $(0.459)$ & $(0.900)$ & $(0.531)$ \\
\hline Discrimination & $-1.696^{* * *}$ & $-2.083^{* *}$ & $-1.615^{* * *}$ \\
& $(0.497)$ & $(0.931)$ & $(0.572)$ \\
\hline$r^{2}$ & 0.086 & 0.124 & 0.078 \\
\hline$n$ & 18,218 & 4,677 & 13,541 \\
\hline
\end{tabular}

Notes: Robust standard errors are in parentheses. ${ }^{*} p<.1,{ }^{* *} p<.05,{ }^{* * *} p<.01$. We cluster standard errors at the household level. We adjust for the demographic and economic variables, home/neighborhood environment, health/lifestyle variables, and social capital variable in all models. The datasets cover the years 2008, 2010, and 2012. The F-test indicates that we can reject the null hypothesis that states all coefficients $=0$. Demographic and economic variables: age, age ${ }^{2}$, gender, household size, number of kids, urban, marital status, education in years, employment status, adjusted total household per capita income, 26 regions of Turkey, and year $\mathrm{f}$ ixed effects. Home/neighborhood environment variables: home noise and home/neighborhood crime or violence. Health/lifestyle variables: alcohol consumption, BMI, and health status. Social capital variable: whether you have someone to trust in case of a serious problem. Work environment variables: rude behavior and discrimination at work.

Finally, to incorporate workplace environment variables, we restrict our sample to employed individuals and report the results in Table 5. The workplace environment measures that we include in our analysis are exposure to rude behavior and discrimination in the workplace. Both women and men report lower levels of mental well-being scores when they are exposed to rude behavior and discrimination in the workplace.

\section{Discussion and Conclusion}

In this study, we have examined the relationship between mental well-being and individual-level socioeconomic and demographic factors such as household income level, age, marital status, and household size among adults in Turkey. We also shed some light on the connection between mental health and factors related to the workplace and home/neighborhood environments. We use a nationally representative rich dataset by combining repeated cross sections of the 2008, 2010, and 2012 THSs to identify the risk factors for mental illness among adults in Turkey. 
We have found women to be more likely to report worse mental well-being than men, and this difference is robust even after adjusting for a broad set of observable characteristics such as income, marital status, education, and number of children. This finding is consistent with the literature, in which women are reported to have a higher likelihood of depression or worse mental health universally, and Turkey is no different. Similar to the evidence from other countries, married people report better mental health according to our findings.

What we have found for the relationship between education and mental health is also consistent with the literature. A lower level of education is significantly associated with adverse mental health outcomes (Creed \& Barsky, 2004). Educated individuals are expected to report greater well-being as a result of earning a higher income in the labor market. In our case, however, a positive relationship between education and mental health scores still holds even after adjusting for household per capita income. Additionally, we held several other characteristics constant that could serve as mechanisms for explaining the association of education with mental health. In the regressions, we adjusted for income, marital status, number of children, health indicators (BMI, self-reported health, alcohol consumption), and workplace environment measures and still found a positive significant association between education and mental health.

Employment status is another important factor associated with mental wellbeing. Existing research suggests mental health problems to be more likely seen in unemployed individuals (Dooley, 2003; Thomas et al., 2005) and unemployed men to be likely to be more distressed than unemployed women (Paul \& Moser, 2009). Our analysis shows employment and mental well-being to be positively related for men at quite a small magnitude (0.98) when controlling for education and family income among other determinants. Meanwhile, employment status was not a significant factor when determining women's mental well-being. This is surprising when one considers the empowering effects of employment. Explanations for working women reporting the same mental health scores as unemployed women could be associated with the large share of women working in unpaid family businesses in agriculture, lack of childcare support, and traditional gender roles that do not praise working women.

Health/lifestyle choices are also significant risk factors determining one's mental health. Alcohol consumption is positively related to experiencing worse mental health for women. Women are also less likely to report that they consume alcohol. Additionally, alcohol consumption is not statistically significantly related 
to mental well-being for employed women. Moreover, despite the presence of findings regarding a significant positive relationship between obesity and mental health disorders (Kelly et al., 2011; McCrea et al., 2012), BMI is not associated with mental well-being for women in our analysis. A positive association exists between mental health and BMI for men; however, the magnitude of the estimated coefficient is close to zero.

The literature has suggested noise, violence, and crime in the neighborhood to be significant factors in predicting mental health (Wilson-Genderson \& Pruchno, 2013; Shiue, 2015). What emerged from our results is consistent with the literature: Exposure to noise at home, violence, and crime at home or in the neighborhood are significantly associated with worse mental health. Stockdale et al. (2007) studied the relationship between neighborhood stressors and mental health disorders. They reported that those exposed to violence in a high-crime environment are more likely to develop mental disorders.

A significant result regarding the variable of social capital has emerged from our analyses. The estimates provide statistically significant evidence that social capital (i.e., trust in others) is positively related to mental health scores. Estimates suggest social capital to be highly correlated with higher MHI-5 scores for both genders.

Among the other determinants of mental health, income is an essential risk factor in understanding poor mental health in such a way that lower income produces poorer mental health outcomes (Lam \& Boey, 2005; Dalgard et al., 2006; Gruebner et al., 2012). However, our results indicate a weak relationship between mental health and household income. For instance, according to the coefficients in Column 1 of Table 4, household per capita income needs to increase by 981 TL (in 2003 Turkish Liras) in order to generate the same increase in MHI-5 scores as the social capital variable of the existence of at least one person to trust in case of a serious problem does. Our findings draw attention to the influence of the non-financial variables that appear to affect human well-being, including being married, home/neighborhood environment, good health, and trusting someone when needed in case of a severe problem. This could link to the aspiration hypothesis, suggesting that well-being is associated to income aspirations rather than the actual income (Stutzer, 2004); this may need further investigation as we are unable to draw concrete conclusions from the available dataset. 
We have also focused on the relationship between mental well-being and rude behavior and discrimination in the workplace. Our findings suggest exposure to rude behavior and discrimination in the workplace to significantly be associated with lower mental health scores for both genders; this is not surprising considering that employed individuals usually spend long hours at work during the day. Lower mental health scores when exposed to discrimination or rude behavior at the workplace may occur as a result of job characteristics as well; however, our dataset does not provide information about the job characteristics, and hence we have been unable to test whether this is the case.

Finally, we want to stress that our results should be interpreted as associations as our econometric specification is not designed to reveal any causal link. Unobserved factors may exist, such as motivation or social network affecting both mental wellbeing and the observed characteristics we incorporated into our regression equations. Our identif ication strategy was unable to eliminate the bias associated with the possibility of these unobserved variables being present. Second, reversed causality between the dependent and independent variables, such as education and mental well-being, is also possible. Our results could indicate that individuals with higher educational attainment have better mental health or people with better mental health may stay in school longer.

Notwithstanding the limitations, we have contributed to the existing literature in identifying the risk factors for mental health by approaching the question from a broad perspective that includes demographic, economic, and social capital variables. We have especially focused on examining the relationship between mental health and the factors related to health/lifestyle choices, home/neighborhood environment, and the workplace. Our study includes some interesting results that may be interpreted as the importance non-financial factors have on mental health. We have found non-f inancial variables including good health, trust in others, workplace discrimination, and rude behavior at the workplace to play a significant role in understanding mental well-being. Our findings also offer valuable policy implications for mental health interventions in terms of the perspective of gender. For instance, while being employed is a significant predictor of good mental health for males, this is not true for females. As such, policies for improving well-being for employed women could be effective. Moreover, exposure to crime or violence at home or in the neighborhood is signif icantly associated with worse mental health for women. Hence, the heterogeneity in these factors should be taken into account while implementing intervention policies for improving mental well-being. 


\section{References | Kaynakça}

Affleck, W., Carmichael, V., \& Whitley, R. (2018). Men's mental health: Social determinants and implications for services. The Canadian Journal of Psychiatry, 63 (9), 581-589.

Ajrouch, K. J., Reisine, S., Lim, S., Sohn, W., \& Ismail, A. (2010). Perceived everyday discrimination and psychological distress: Does social support matter? Ethnicity \& Health, 15 (4), 417-434.

Akdag, R. (2011). Turkey health transformation program: Assessment Report (2003-2011). Ankara: Ministry of Health Publication.

Berwick, D. M., Murphy, J. M., Goldman, P. A., Ware, J.E. Jr., Barsky, A.J., \& Weinstein, M.C. (1991). Performance of a five-item mental health screening test. Med Care, 29, 169-176.

Billings, A. C., \& Moos, R. H. (1982). Psychosocial theory and research on depression: an integrative framework and review. Clinical Psychology Review, 2 (2), 213-237.

Brisson, D., Lopez, A., \& Yoder, J. (2014). Neighborhoods and mental health trajectories of low-income mothers. Journal of Community Psychology, 42(5), 519-529.

Caron, J., Fleury, M. J., Perreault, M., Crocker, A., Tremblay, J., Tousignant. M., Kestens, Y., Cargo, Margeret., \& Daniel, M. (2012). Prevalence of psychological distress and mental disorders, and use of mental health services in the epidemiological catchment area of Montreal South-West. BMC Psychiatry, 12 (1), 183.

Chou, K. L., \& Cheung, K. C. K. (2013). Major depressive disorder in vulnerable groups of older adults, their course and treatment, and psychiatric comorbidity. Depression and Anxiety, 30 (6), 528-537.

Creed, F., \& Barsky, A. (2004). A systematic review of the epidemiology of somatisation disorder and hypochondriasis. Journal of Psychosomatic Research, 56 (4), 391-408.

Dalgard, O. S., Thapa, S. B., Hauff, E., McCubbin, M., \& Syed, H. R. (2006). Immigration, lack of control and psychological distress: Findings from the Oslo Health Study. Scandinavian Journal of Psychology, 47(6), 551-558.

Dong, X., Chen, R., Li, C., \& Simon, M. A. (2014). Understanding depressive symptoms among community-dwelling Chinese older adults in the greater Chicago area. Journal of Aging and Health, 26 (7), 1155-1171.

Dooley, D. (2003). Unemployment, underemployment, and mental health: Conceptualizing employment status as a continuum. American Journal of Community Psychology, 32 (1-2), 9-20.

Dumludag, D. (2013). Life satisfaction and income comparison effects in Turkey. Social Indicators Research, 114 (3), 1199-1210.

Eren, K. A., \& Aşıc1, A. A. (2017). The determinants of happiness in Turkey: Evidence from city-level data. Journal of Happiness Studies, 18 (3), 647-669.

Fone, D., Dunstan, F., Williams, G., Lloyd, K., \& Palmer, S. (2007). Places, people and mental health: A multilevel analysis of economic inactivity. Social Science \& Medicine, 64 (3), 633-645.

Fone, D., Greene, G., Farewell, D., White, J., Kelly, M., \& Dunstan, F. (2013). Common mental disorders, neighbourhood income inequality and income deprivation: small-area multilevel analysis. The British Journal of Psychiatry, 202 (4), 286-293.

Fujiwara, T., \& Kawachi, I. (2008). A prospective study of individual-level social capital and major depression in the United States. Journal of Epidemiology \& Community Health, 62 (7), 627-633.

Fujiwara, T., \& Kawachi, I. (2008). Social capital and health: A study of adult twins in the US. American Journal of Preventive Medicine, 35 (2), 139-144.

Gale, C. R., Dennison, E. M., Cooper, C., \& Sayer, A. A. (2011). Neighbourhood environment and positive mental health in older people: The Hertfordshire Cohort Study. Health \& Place, 17 (4), 867-874.

Gao, J., Weaver, S. R., Dai, J., Jia, Y., Liu, X., Jin, K., \& Fu, H. (2014). Workplace social capital and mental health among Chinese employees: A multi-level, cross-sectional study. PLoS ONE, 9 (1), e85005.

Gary, T. L., Stark, S. A., \& LaVeist, T. A. (2007). Neighborhood characteristics and mental health among African Americans and whites living in a racially integrated urban community. Health \& Place, 13 (2), 569-575.

German, L., Kahana, C., Rosenfeld, V., Zabrowsky, I., Wiezer, Z., Fraser, D., \& Shahar, D. R. (2011). Depressive 


\section{insan \& toplum}

symptoms are associated with food insufficiency and nutritional deficiencies in poor community-dwelling elderly people. The Journal of Nutrition, Health \& Aging, 15(1), 3-8.

Gorn, S. B., Sainz, M. T., \& Icaza, M. E. M. M. (2005). Demographic variables related to depression: Differences between males and females living in low income urban-areas. Salud Mental, 28(6), 33-40.

Gruebner, O., Khan, M. M. H., Lautenbach, S., Müller, D., Krämer, A., Lakes, T., \& Hostert, P. (2012). Mental health in the slums of Dhaka-a geoepidemiological study. BMC Public Health, 12(1), 177.

Hamad, R., Fernald, L. C. H., Karlan, D. S., \& Zinman, J. (2008). Social and economic correlates of depressive symptoms and perceived stress in South African adults. Journal of Epidemiology \& Community Health, 62(6), 538-544.

Henderson, C., Roux, A. V. D., Jacobs, D. R., Kiefe, C. I., West, D., \& Williams, D. R. (2005). Neighbourhood characteristics, individual level socioeconomic factors, and depressive symptoms in young adults: The CARDIA study. Journal of Epidemiology \& Community Health, 59(4), 322-328.

Jokela, M. (2014). Are neighborhood health associations causal? A 10-year prospective cohort study with repeated measurements. American Journal of Epidemiology, 180(8), 776-784.

Joutsenniemi, K., Martelin, T., Martikainen, P., Pirkola, S., \& Koskinen, S. (2006). Living arrangements and mental health in Finland. Journal of Epidemiology \& Community Health, 60(6), 468-475.

Kelly, S. J., Daniel, M., Dal Grande, E., \& Taylor, A. (2011). Mental ill-health across the continuum of body mass index. BMC Public Health, 11(1), 765.

Kendler, K. S., \& Gardner, C. O. (2014). Sex differences in the pathways to major depression: A study of opposite-sex twin pairs. American Journal of Psychiatry, 171(4), 426-435.

Kim, D. (2008). Blues from the neighborhood? Neighborhood characteristics and depression. Epidemiologic Reviews, 30(1), 101-117.

Kose, T. (2020). Gender, income and mental health: The Turkish case. PLoS ONE, 15(4), e0232344.

Lam, C. W., \& Boey, K. W. (2005). The psychological well-being of the Chinese elderly living in old urban areas of Hong Kong: A social perspective. Aging \& Mental Health, 9(2), 162-166.

McCrea, R. L., Berger, Y. G., \& King, M. B. (2012). Body mass index and common mental disorders: Exploring the shape of the association and its moderation by age, gender and education. International Journal of Obesity, 36(3), 414-421.

Miranda, J., Siddique, J., Belin, T. R., \& Kohn-Wood, L. P. (2005). Depression prevalence in disadvantaged young black women. Social Psychiatry and Psychiatric Epidemiology, 40(4), 253-258.

Mundt, A., Kliewe, T., Yayla, S., Ignatyev, Y., Busch, M. A., Heimann, H., ... \& Aichberger, M. C. (2014). Social characteristics of psychological distress in disadvantaged areas of Berlin. International Journal of Social Psychiatry, 60(1), 75-82.

Organisation for Economic Co-operation and Development (2017). Health at a glance 2017: OECD indicators. Paris, France: Author. Retrieved from https://doi.org/10.1787/4dd50c09-en

Organisation for Economic Co-operation and Development (2019). Health at a glance 2019: OECD indicators. Paris, France: Author. Retrieved from https://doi.org/10.1787/4dd50c09-en

Oshio, T., Umeda, M., \& Kawakami, N. (2013). Impact of interpersonal adversity in childhood on adult mental health: How much is mediated by social support and socio-economic status in Japan? Public Health, 127(8), 754-760.

Özden, S. A., \& Çoban, A. İ. (2018). Community based mental health services, in the eye of community mental health professionals. Journal of Psychiatric Nursing/Psikiyatri Hemsireleri Dernegi, 9(3), 186-194.

Paul, K. I., \& Moser, K. (2009). Unemployment impairs mental health: Meta-analyses. Journal of Vocational Behavior, 74(3), 264-282.

Rumpf, H.J., Meyer, C., Hapke, U., \& John, U. (2001).Screening for mental health: Validity of the MHI-5 using DSMIV Axis I psychiatric disorders as gold standard. Psychiatry Research, 105, 243-253.

Selim, S. (2008). Life satisfaction and happiness in Turkey. Social Indicators Research, 88(3), 531-562.

Shiue, I. (2015). Neighborhood epidemiological monitoring and adult mental health: European Quality of Life Survey, 
2007-2012. Environmental Science and Pollution Research, 22(8), 6095-6103.

Silva, M., Loureiro, A., \& Cardoso, G. (2016). Social determinants of mental health: A review of the evidence. The European Journal of Psychiatry, 30(4), 259-292.

Sorsdahl, K., Slopen, N., Siefert, K., Seedat, S., Stein, D. J., \& Williams, D. R. (2011). Household food insufficiency and mental health in South Africa. Journal of Epidemiology \& Community Health, 65(5), 426-431.

Stankunas, M., Kalediene, R., Starkuviene, S., \& Kapustinskiene, V. (2006). Duration of unemployment and depression: A cross-sectional survey in Lithuania. BMC Public Health, 6(1), 174.

Stockdale, S. E., Wells, K. B., Tang, L., Belin, T. R., Zhang, L., \& Sherbourne, C. D. (2007). The importance of social context: Neighborhood stressors, stress-buffering mechanisms, and alcohol, drug, and mental health disorders. Social Science \& Medicine, 65(9), 1867-1881.

Stutzer, A. (2004). The role of income aspirations in individual happiness. Journal of Economic Behavior \& Organization, 54(1), 89-109.

Thomas, C., Benzeval, M., \& Stansfeld, S. A. (2005). Employment transitions and mental health: An analysis from the British household panel survey. Journal of Epidemiology \& Community Health, 59(3), 243-249.

Tirgil, A., Gurol-Urganci, I., \& Atun, R. (2018). Early experience of universal health coverage in Turkey on access to health services for the poor: Regression kink design analysis. Journal of Global Health, 8(2).

Turkish Statistical Institute (2019). Death statistics. Retrieved from: https://data.tuik.gov.tr/Bulten/Index?p=DeathStatistics-2018-30701

Turkish Statistical Institute (2018). Ulusal eğitim istatistikleri veri tabanı, Retrieved from: https://tuikweb.tuik. gov.tr/PreTablo.do?alt id $=1018$

Wilson-Genderson, M., \& Pruchno, R. (2013). Effects of neighborhood violence and perceptions of neighborhood safety on depressive symptoms of older adults. Social Science \& Medicine, 85, 43-49.

Ware, J.E., Snow, K.K., Kosinski, M., \& Gandek, B. (1993). SF-36 health survey manual \& interpretation guide Boston, MA: New England Medical Center.

World Bank. (2020). GDP. Retrieved from: https://data.worldbank.org/indicator/NY.GDP.MKTP.CD

World Health Organization. (2005). Promoting mental health: Concepts, emerging evidence, practice: A report of the World Health Organization, Department of Mental Health and Substance Abuse in collaboration with the Victorian Health Promotion Foundation and the University of Melbourne. Author.

Yamazaki, S., Fukuhara, S., \& Green, J. (2005). Usefulness of five-item and three-item Mental Health Inventories to screen for depressive symptoms in the general population of Japan. Health and Quality of Life Outcomes, 3(1), 48. 